\title{
In vitro anticolon antibody production by mucosal or peripheral blood lymphocytes from patients with ulcerative colitis
}

T Hibi, M Ohara, K Toda, A Hara, H Ogata, Y Iwao, N Watanabe, M Watanabe, Y Hamada, K Kobayashi, S Aiso, M Tsuchiya

\begin{abstract}
Serum anticolon antibody and in vitro anticolon antibody production by peripheral blood and mucosal lymphocytes was investigated in patients with ulcerative colitis. The frequency of serum anticolon antibody was $71 \%$ in 41 patients with ulcerative colitis, estimated by enzyme linked immunosorbent assay (ELISA) using isolated rat colon epithelial cells. This finding confirms our previous report on the frequency of serum anticolon antibody detected by flow cytometry analysis. The estimated frequencies of IgG anticolon antibody secreting cells were $1 \cdot 5-12 \cdot 5 / 10^{6}$ cells in the colonic mucosa and $0 \cdot 1-0 \cdot 5 / 10^{6}$ cells in peripheral blood, from patients with ulcerative colitis when Epstein-Barr virus (EBV) was used as a B cell polyclonal activator. Poisson analysis of limiting dilution culture showed that about one per $14 \mathrm{C}$ IgG cells in the colonic mucosa synthesised anticolon antibody. Two monoclonal IgG antibodies were obtained from EBV transformed anticolon antibody secreting cells by limiting dilution method. One reacted with goblet cells in the intestine, and the other reacted mainly with colonic epithelial cells. These results suggest that heterogeneous anticolon antibodies are present in patients with ulcerative colitis and that colonic mucosa may be the main source of anticolon antibody. Local autoimmune reaction might have an important role in causing the inflammation of colonic mucosa in this disease.
\end{abstract}

Several lines of evidence suggest that autoimmune mechanisms may be concerned in the pathogenesis of ulcerative colitis. ${ }^{14}$ Autoantibodies that react with colonic epithelial cells are frequently found in the sera of patients with this disease. ${ }^{5}$ Our previous study using flow cytometry showed that the frequency of anticolon antibodies in the sera from patients with ulcerative colitis was $78 \%{ }^{4}$ The properties of these antibodies have not been well explained. There are several reports that antibody dependent cell mediated cytotoxicity causes the lysis of colonic epithelial cells. ${ }^{6-9} \mathrm{~A}$ sensitive and simple assay for detecting anticolon antibodies has been developed using isolated colon epithelial cells. This has allowed screening for anticolon antibodies in the serum or culture supernatant. We examined whether peripheral blood or colon lymphocytes secreting anticolon antibodies could be detected in vitro in patients with ulcerative colitis, using Epstein-Barr virus (EBV) as a polyclonal B lymphocyte activator. In addition, monoclonal cell lines which could produce anticolon antibodies were established by limiting dilution and the characteristics of colon specific antigens were investigated by these antibodies.

\section{Methods}

\section{SERA}

Ulcerative colitis was diagnosed on the basis of typical clinical, radiographic, and pathological features. Sera were obtained from 41 patients with ulcerative colitis and 27 healthy hospital workers. The sex and age distribution of the healthy control group was comparable to that of the patients. The sera from 11 patients with Crohn's disease, nine patients with colon cancer, and five patients with colon diverticulosis were also examined. Sera were stored at $-80^{\circ} \mathrm{C}$ without preservatives and centrifuged at $105000 \mathrm{~g}$ for 90 minutes before use.

\section{LYMPHOCYTE PREPARATION}

Peripheral blood lymphocytes were isolated from heparinised blood using a Ficoll-Hypaque density gradient and washed three times in Hanks's balanced salt solution. Colon lymphocytes were isolated from the colonic mucosa which was obtained at operation by a modification of the method of Bookman and Bull. ${ }^{10}$ The colonic mucosa was obtained from fresh specimens resected surgically. The mucosa was dissected out of underlying muscle layers and cut into small pieces with iris scissors. After washing with calcium and magnesium-free Hanks's solution, the mucosa was incubated and stirred for 5 minutes at $22^{\circ} \mathrm{C}$ in calcium and magnesium-free Hanks's solution containing $0.5 \mathrm{mM}$ dithiothreitol. The tissue was then washed, incubated, and stirred for 60 minutes at $37^{\circ} \mathrm{C}$ in calcium and magnesium-free Hanks's solution containing $0.75 \mathrm{mM}$ ethylenediamine tetra-acetate to remove epithelial cells. The supernatant was decanted and the remaining tissue was incubated and stirred at $37^{\circ} \mathrm{C}$ in a $5 \% \mathrm{CO}_{2}$ in RPMI 1640 medium containing antibiotics, $10 \%$ fetal calf serum, and $20 \mathrm{U} / \mathrm{ml}$ collagenase (CLSPA, Worthington Biochemical Corp, Freehold, New Jersey, USA) for 18 hours. The crude cell suspension was filtered through $50 \mu \mathrm{m}$ stainless mesh and then washed. After being resuspended in $100 \%$ fetal calf serum the cell suspension was separated over Ficoll-Hypaque. The resultant cell lymphoid cell suspension was washed and resuspended in complete medium (RPMI 1640 
supplemented with antibiotics, $2 \mathrm{mM}$ L-glutamine, $10 \%$ fetal calf serum, and $50 \mu \mathrm{m}$ 2-mercaptoethanol).

\section{PREPARATION OF EBV}

EBV was obtained from the culture supernatant of the B95-8 marmoset cell line. B95-8 cells were cultured at a concentration of $10^{6} \mathrm{cells} / \mathrm{ml}$ and incubated for $10-14$ days at $37^{\circ} \mathrm{C}$ for virus production. The virus-containing supernatant was filtered through a $0.45 \mu \mathrm{m}$ millipore filter and stored at $-80^{\circ} \mathrm{C}$.

\section{EBV TRANSFORMATION}

$5 \times 10^{6}$ lymphocytes were suspended in $5 \mathrm{ml}$ of the culture supernatant of B95-8 cell line and then washed once with complete medium. $1 \times 10^{4}$ cells exposed to EBV were seeded in each well of a 96 well plate or $1-2 \times 10^{5}$ cells were seeded in each well of a 24 well plate. Plates were incubated in $5 \% \mathrm{CO}_{2}$ at $37^{\circ} \mathrm{C}$. At weekly intervals two thirds of the medium was removed and replaced with fresh medium. At the cell densities used in these experiments all cultures were transformed. Three or four weeks after the cultures were initiated supernatant from each well was harvested and screened for anticolon antibody secretion in an enzyme linked immunosorbent assay (ELISA) designed to detect antibody to colon epithelial cell.

To estimate the frequencies of anticolon antibody secreting cells, the following formula was used.

Frequency of anticolon antibody secreting cells

$$
=\frac{\text { number of ELISA positive wells }}{\text { number of cells per well } \times \text { number of wells }}
$$

\section{LIMITING DILUTION ANALYSIS}

Mucosal lymphocytes obtained from a patient with ulcerative colitis were tested by limiting dilution cultures. One hundred to $500000 \mathrm{EBV}$ infected lymphocytes per microtiter well were cultured in $200 \mu \mathrm{l}$ of complete medium for four weeks. At least 40 replicate wells were used for seven cell doses. Two thirds of the culture supernatant was replaced with fresh complete medium weekly. The culture supernatant from each well was tested for anticolon antibody secretion and for immunoglobulin G (IgG) secretion by ELISA. The frequency of IgG secreting cells and anticolon antibody secreting cells was calculated by three statistical methods, maximum likelihood, weighted mean, and minimum $\chi^{2}$.

\section{SCREENING FOR ANTIBODIES}

The epithelial cells were isolated from Wistar rat colon, as described in our previous paper. ${ }^{4} 5 \times 10^{4}$ cells were incubated overnight in 96 well plates and fixed with $0.5 \%$ glutaraldehyde in phosphate buffered saline for 5 minutes at room temperature. After washing with phosphate buffered saline, fixed colon cells were incubated with $100 \mu l$ of the culture medium from each well of EBV transformed cells or 1:50 diluted serum.
The culture supernatant from EBV transformed cell lines, which produce a large amount of IgG or IgM but not anticolon antibody, was used as the negative control. The serum from patients with ulcerative colitis and high activity of anticolon antibody served as the positive control. For the absorption study human or rat colon epithelial cells were isolated by the same method as mentioned above. Homogenised human colon mucosa was also used for the absorption study. After 1 hour incubation at $37^{\circ} \mathrm{C}$ the cells were washed three times with phosphate buffered saline and then incubated at room temperature for 1 hour with $100 \mu$ l of a 1:2500 dilution of goat antihuman IgG or goat antihuman IgM, conjugated to alkaline phosphatase (Tago, Burlingame CA, USA). The cells were then washed with phosphate buffered saline and incubated with $100 \mu \mathrm{l}$ of $0.5 \mathrm{mM}$ p-nitrophenylphosphate. The optical density was read at $409 \mathrm{~nm}$ with TOYO EYT-III ELISA reader (Toyo, Tokyo, Japan). Wells with optical densities greater than the two standard deviations above the mean of the negative controls were scored as positive for anticolon antibody activity.

The binding of antibodies to rat colon epithelial cells was also determined by fluorescence activated cell sorter analysis described previously. ${ }^{47}$ Briefly, one million epithelial cells were incubated with $100 \mu$ l undiluted serum or culture supernatant at room temperature for 30 minutes and washed three times with RPMI 1640 medium. Washed cells were incubated with $100 \mu$ l FITC conjugated $\left(\mathrm{Fab}^{\prime}\right) 2$ fragments of rabbit antihuman $\operatorname{Ig}(\mathrm{G}+\mathrm{A}+\mathrm{M})$ (Cappel Laboratories, Downington PA, USA) at room temperature for 30 minutes. After washing, the cells were resuspended and then filtered through a $400 \mu \mathrm{m}$ nylon mesh. The cell suspensions were then analysed with the FACS-II (Becton-Dickinson, Mountain View CA, USA). For the measurement of IgG or IgM secreted into culture supernatants, a standard ELISA sandwich procedure was used.

\section{CLONING}

EBV transformed cell cultures secreting anticolon antibodies were cloned by limiting dilution $(0.5 \mathrm{cell} / 200 \mu \mathrm{l}$ per well) on feeder layers consisting of $10^{5}$ human cord blood lymphocytes treated with 2500 rad radiation in 96 well culture plates.

\section{REACTIVITY OF ANTICOLON ANTIBODIES}

Fresh tissues were obtained from Wistar rat and snap-frozen in OCT embedding medium (Miles, Elkhart IN, USA). Human colonic mucosa was obtained at operation for colon cancer. Frozen sections were cut at $4 \mu \mathrm{m}$ and allowed to air dry for 1 hour. After fixation with acetone for 1 second the sections were stained by indirect immunofluorescence or immunoperoxidase technique using avidin-biotin complexes. For the staining the culture supernatant of cloned cell lines was used as first antibody and FITC conjugated or biotin conjugated antihuman IgG was used as second antibody. In addition, human colon cancer cell line, colo205, and hepatic cancer cell line, HCCM, were tested for the 


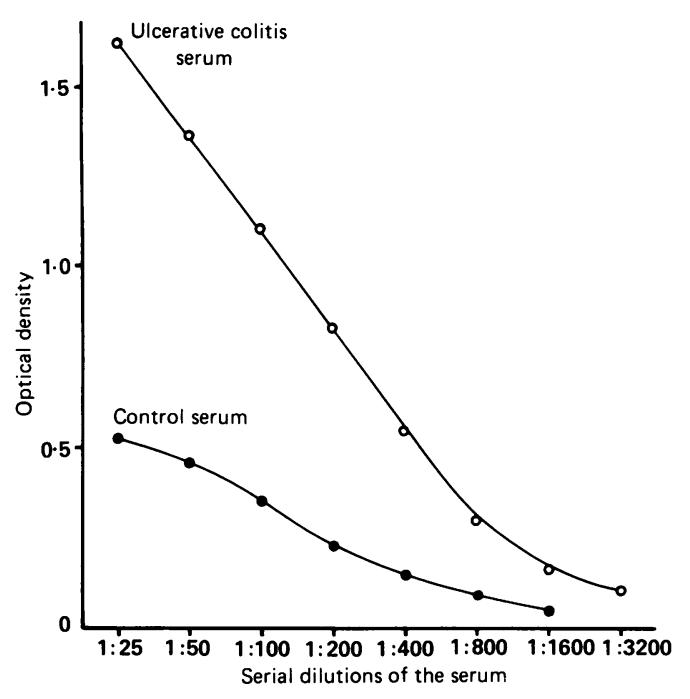

Figure 1: Reaction of the serum against colon epithelial cells in serial dilutions. The serum from a patient with ulcerative colitis and a healthy control subject was serially diluted and tested for the binding to rat colon epithelial cells in an enzyme linked immunosorbent assay. In any dilution the serum from a patient with ulcerative colitis showed higher optical density than the serum from a healthy control subject.

reactivity of these monoclonal antibodies with indirect immunofluorescence.

\section{Results}

\section{SERUM ANTICOLON ANTIBODY}

To find out the proper dilution of the serum in the ELISA, the serum with high activity for anticolon antibody ascertained by fluorescence activator cell sorter analysis was tested in serial dilution. A representative experiment is shown in Figure 1. In comparison with normal serum the optical density of the patient's serum was high in any dilution tested (Fig 1). The differences in optical densities were remarkable in $1: 25$ or $1: 50$ dilution of the serum. In the following experiments 1:50 dilution was used. To examine the specificity of this assay absorption studies were undertaken on two sera with high activity for anticolon antibody. The sera were incubated with $1 \times 10^{8}$ rat or human colon epithelial cells for 3 hours at room temperature. The optical densities of these treated sera were reduced in comparison with those of the untreated sera and were similar to those of healthy control sera. Similarly, absorption with homogenised human colon mucosa abolished the reactivity of the sera to rat colon epithelial cells. It is possible that the non-specific binding of the serum IgG through $\mathrm{Fc}$ receptor on rat colon epithelial cells is also measured in this assay. To determine if the non-specific binding of the serum IgG influenced the ELISA, the following experiments were performed in eight positive sera. A large amount of purified rat IgG (CappelOrganon Teknika Corp, PA) (100 times higher than the normal concentration of IgG in the serum) was added to the serum to block the nonspecific binding of IgG in the tested serum. Then the optical densities of the treated sera were compared with those of the untreated sera. There was no significant difference between the optical densities of the sera added with a large amount of IgG (mean (2SD), $0.861(0 \cdot 202))$ and those of the untreated sera $(0 \cdot 847(0 \cdot 249))$. This meant that this assay did not pick up the nonspecific binding of IgG to the colonic epithelial cells. The absorption studies using human erythrocytes were performed, since the cross reactivity of rat colon antigens and human blood group A antigens has been reported by Hammarstrom et al. ${ }^{11}$ Packed and washed human A type erythrocytes were mixed with equal volumes of undiluted serum and the mixtures were incubated for 30 minutes at room temperature. The optical densities of the absorbed sera were compared with those of the unabsorbed sera. There was no significant difference in anticolon antibody activity between the unabsorbed sera (mean (2SD), $1 \cdot 188(0 \cdot 329)$ ) and the absorbed sera $(0.928(0 \cdot 380))$.

The correlation between the optical density in ELISA and per cent of fluorescence positive cells in fluorescence activated cell sorter analysis were tested in patients' sera. There was a significant correlation $(r=0.578, p<0.05)$. The frequency of anticolon antibodies is shown in Figure 2. In the patients with ulcerative colitis there was a significant increase in the optical densities (mean (2SD) $0.852(0.279))$ compared with healthy control subjects $(0.470(0 \cdot 142))$. When the optical densities greater than two standard deviations above the mean of the healthy controls were scored as positive for anticolon antibody activity, the frequency of anticolon antibody was $71 \%$ in patients with ulcerative colitis. The sera from patients with Crohn's disease did not show high optical densities, but two sera were positive for anticolon antibody activity. The optical densities of the sera from nine patients with colon cancer and from five patients with colon diverticulosis were $0.383(0.116)$ and $0.319(0.08)$. These were not significantly higher than the optical densities of healthy control sera.

\section{FREQUENCIES OF ANTICOLON ANTIBODY \\ SECRETING CELLS IN MACROCULTURES}

Estimated frequencies of anticolon antibody secreting EBV transformed cells, expressed as the number of anticolon antibody secreting cells, are shown in Table I. The number of IgG anticolon antibody secreting cells varied from $1 \cdot 5-12 \cdot 5 / 10^{6}$ colonic mucosal lymphocytes. The number of $\operatorname{IgM}$ anticolon antibody secreting cells was $0.5 / 10^{6}$ cells in experiment III. In peripheral blood of ulcerative colitis patients the estimated frequencies of IgG anticolon secreting cells were $0 \cdot 4-0 \cdot 5 / 10^{6}$ cells. As shown in Table II the estimated frequencies of anticolon antibody secreting EBV transformed cells in healthy control subjects or in patients with other diseases were very low. Anticolon antibody secreting cells were induced in one per 48 wells of colonic lymphocyte culture from a patient with colon cancer and in one per 96 wells of peripheral blood lymphocyte culture from a healthy control subject. The anticolon antibody secreting cells from patients with ulcerative colitis were cloned by limiting dilution culture. Although the cloning efficiency was low, two IgG cell lines $\left(\mathrm{CA} 6 \mathrm{H}_{3}\right.$, DB5 $\left.B_{11}\right)$ and one IgM cell line (CB3 $M$ ), which reacted with rat colon epithelial cells by ELISA 


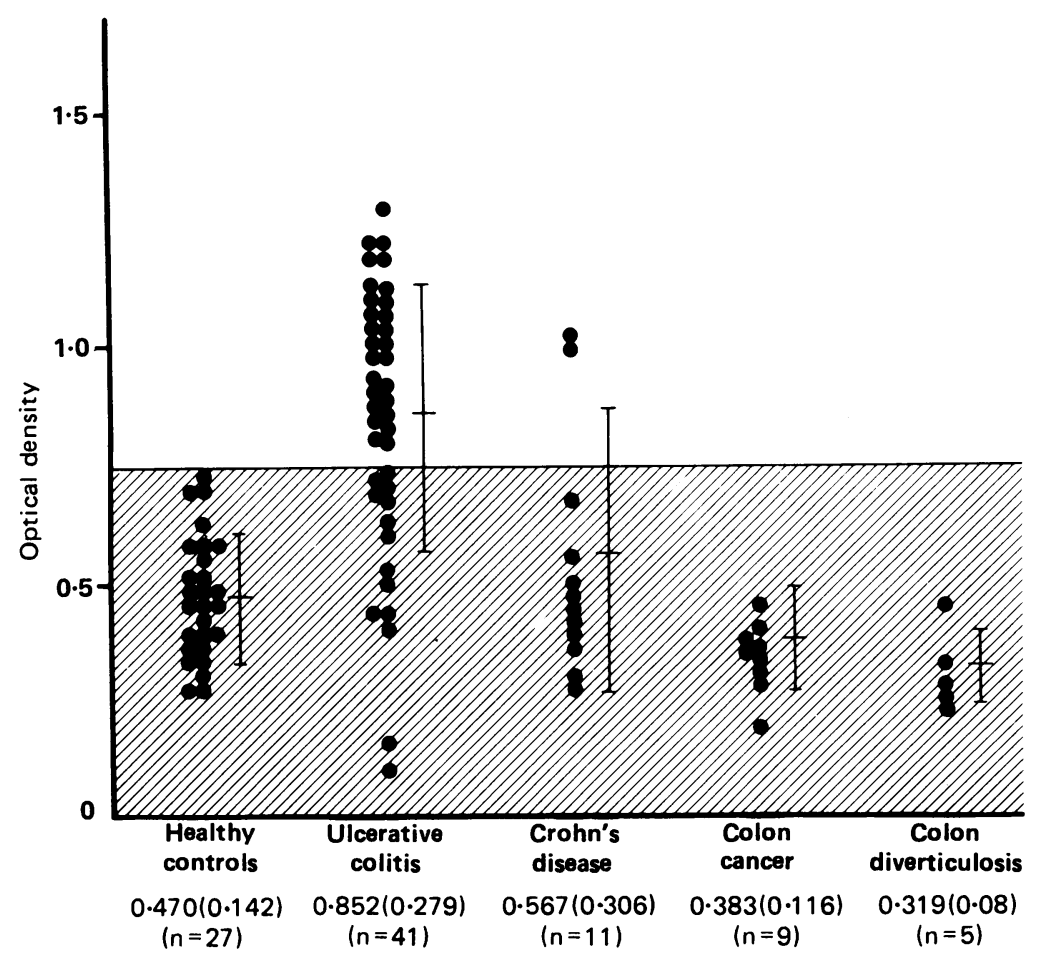

Figure 2: Anticolon antibody in the sera from healthy control subjects and patients with intestinal diseases. The mean (2SD) value of optical densities in the sera of patients with ulcerative colitis taken as a group was statistically higher than that obtained in healthy controls $(0.852(0.279) \mathrm{v} 0.470(0.142), p<0.01)$. The optical densities in the sera from patients with Crohn's disease, colon cancer, and colon diverticulosis were $0.567(0 \cdot 306), 0 \cdot 383(0 \cdot 116)$, and $0.319(0.08)$ respectively. These values were not different from the optical densities in healthy controls.

and fluorescence activated cell sorter analysis, were isolated as shown in Table III. The cell lines generally secreted $1-10 \mu \mathrm{g} \operatorname{IgG}$ or $\operatorname{IgM} / \mathrm{ml}$ of culture supernatant.

\section{FREQUENCIES OF TOTAL IGG SECRETING CELLS AND ANTICOLON ANTIBODY SECRETING CELLS IN LIMITING DILUTION CULTURE}

The estimated frequencies of total IgG secreting cells or anticolon antibody secreting cells were not different as calculated by the three statistical methods. The acceptability of the data with the Poisson single hit kinetics was confirmed by the fact that $\chi^{2}$-derived probability values of 0.79 to 1.55 were well above the $p=0.05$ level. This experiment showed that about one per $140 \mathrm{IgG}$

TABLE I Estimated frequencies of anticolon antibody producing E pstein-Barr virus transformed cells of mucosal or peripheral blood lymphocytes from control subjects (normal, colon cancer, colon diverticulosis)

\begin{tabular}{|c|c|c|c|c|c|}
\hline & $\begin{array}{l}\text { No of } \\
\text { culture } \\
\text { wells }\end{array}$ & $\begin{array}{l}\text { No of } \\
\text { cells per } \\
\text { well }\end{array}$ & $\begin{array}{l}\text { No of } \\
\text { ELISA } \\
\text { positive wells }\end{array}$ & $\begin{array}{l}\text { Calculated frequency } \\
\text { of anticolon antibody } \\
\text { producing cells } \\
\text { (per } 10^{\circ} \text { cells) }\end{array}$ & Ig class \\
\hline \multicolumn{6}{|l|}{ Colon cancer: } \\
\hline Exp I (mucosal) & 48 & $1 \times 10^{5}$ & 1 & $0 \cdot 2$ & IgG \\
\hline Exp II (mucosal) & 45 & $1 \times 10^{5}$ & 0 & 0 & - \\
\hline Exp III (peripheral blood) & 45 & $1 \times 10^{5}$ & 0 & 0 & - \\
\hline \multicolumn{6}{|l|}{ Colon diverticulosis: } \\
\hline Exp IV (mucosal) & 48 & $1 \times 10^{5}$ & 0 & 0 & - \\
\hline Exp V (peripheral blood) & 45 & $1 \times 10^{5}$ & 0 & 0 & - \\
\hline \multicolumn{6}{|l|}{ Healthy control subject: } \\
\hline Exp VI (peripheral blood) & 48 & $1 \times 10^{5}$ & 0 & 0 & - \\
\hline Exp VII (peripheral blood) & 48 & $1 \times 10^{5}$ & 0 & 0 & - \\
\hline Exp VIII (peripheral blood) & 45 & $1 \times 10^{5}$ & 0 & 0 & - \\
\hline Exp IX (peripheral blood) & 96 & $1 \times 10$ & 1 & $0 \cdot 1$ & IgG \\
\hline
\end{tabular}

$\star$ Frequency $=\frac{\text { No of ELISA positive wells }}{\text { No of cells per well } \times \text { number of wells }}$ secreting cells produced anticolon antibody in the colonic mucosa of a patient with ulcerative colitis.

\section{REACTIVITY OF MONOCLONAL ANTIBODIES} (FIGURE 3)

Reactivity of those antibodies was examined by indirect immunofluorescence or immunoperoxidase methods. All three antibodies reacted with rat colon epithelial cells, human colon epithelial cells, and colo 205 cancer cell line by indirect immunofluorescence. Human hepatic cell carcinoma cell line, HCCM, was not stained by any of these antibodies. Two IgG antibodies were further tested for reactivity with various kinds of rat tissues by immunohistochemistry. One $\left(\mathrm{CA} 6 \mathrm{H}_{3}\right)$ reacted with the apical portion of colon epithelial cells, and the other (DB5 $\mathrm{B}_{11}$ ) reacted mainly with goblet cells in the intestine. The staining intensity was not altered by the excess of purified human IgG when it was put before the first antibodies. Neither of these antibodies reacted with heart, spleen, kidney, liver, oesophagus, or stomach.

\section{Discussion}

This study has shown that about $71 \%$ of 41 patients with ulcerative colitis have circulating antibody against colon epithelial cells and that ELISA, using isolated rat colon epithelial cells, is suitable for the screening of large numbers of sera or culture supernatants of EBV transformed cells for the antibody activity to colonic epithelial cells. The frequency of serum anticolon antibody in this study is similar to that detected by fluorescence activated cell sorter analysis reported previously. ${ }^{4}$ It is remarkably high in comparison with the earlier reports where circulating anticolon antibodies were detected in $15-40 \%$ of patients with ulcerative colitis. ${ }^{12-14}$ ELISA is comparable in sensitivity to fluorescence activator cell sorter analysis for the screening of anticolon antibody, but is more rapid and requires less expensive equipment. Using this simple assay we measured the anticolon antibody activity in culture supernatant of lymphocytes.

To assess the validity of in vitro anticolon antibody production we first used a system of pokeweed mitogen-induced antibody response. Mucosal or peripheral blood lymphocytes from patients with ulcerative colitis showed little or no synthesis of anticolon antibody spontaneously or in pokeweed mitogen stimulation (data not shown). EBV was thus used as a polyclonal B cell activator in this study. EBV infects human B

TABLE II Anticolon antibody activity of Epstein-Barr virus transformed cell lines by enzyme linked immunosorbent assay (ELISA)

\begin{tabular}{lll}
\hline Cell lines & Ig class & $\begin{array}{l}\text { Anticolon antibody } \\
\text { activity by ELISA } \\
\text { (optical density) }(\text { mean }(2 S D))\end{array}$ \\
\hline Culture medium & - & $0.030(0.014)$ \\
$8-1 \mathrm{~A}_{1}$ & $\operatorname{IgG}(x)$ & $0.025(0.003)$ \\
$8-1 \mathrm{~B}_{2}$ & $\operatorname{IgG}(\lambda)$ & $0.015(0.002)$ \\
CA 6 H & $\operatorname{IgG}(x)$ & $1.557(0.021)$ \\
DB 5 B & $\operatorname{IgG}(\lambda)$ & $1.541(0.020)$ \\
CB 3 M & $\operatorname{IgM}(-)$ & $1.502(0.057)$ \\
\hline
\end{tabular}



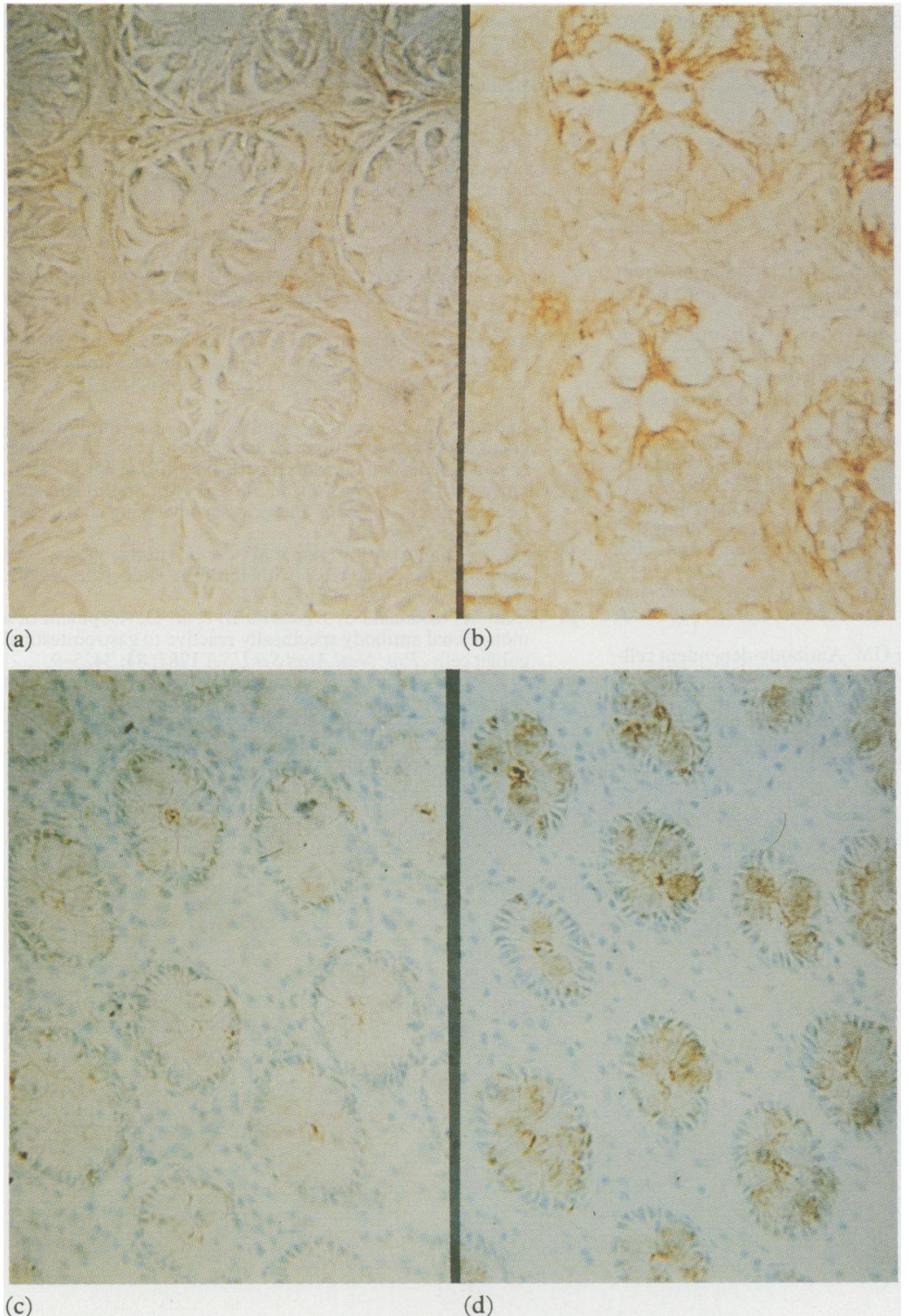

Figure 3: Reactions of the monoclonal antibodies from Epstein-Barr virus transformed cell lines. (a) The staining of rat colon tissue by $\mathrm{CA}_{6} \mathrm{H}_{3}$. The apical and lateral portions of epithelial cells were stained. (b) The staining of rat colon tissue by control medium from 8-1 AI. No goblet or epithelial cells were stained. (c) The staining of rat colon tissue by $D B 5 B_{11}$. The goblet cells of colonic mucosa were specifically stained. (d) The staining of rat colon tissue by control medium from 8-1 B2. No goblet cells were stained.

cells and makes these cells transform and secrete large amounts of immunoglobulins, although a small fraction of human $B$ cells can be activated by EBV to secrete immunoglobulins. ${ }^{15}$ By transforming human B lymphocytes of colonic mucosa or peripheral blood of patients with ulcerative colitis by EBV infection, large amounts of anticolon antibody production were

TABLE III Frequency of Epstein-Barr transformed lymphocytes analysed by three statistical methods

\begin{tabular}{|c|c|c|c|}
\hline & $\begin{array}{l}\text { Frequency of } \\
\text { secreting cells } \\
\text { per } 10^{6} \text { cells } \\
(\text { mean }(S E))\end{array}$ & $I / F(S E)$ & $\chi^{2}(d f)$ \\
\hline \multicolumn{4}{|l|}{ IgG: } \\
\hline $\begin{array}{l}\text { Weighted mean } \\
\text { Maximum likelihood } \\
\text { Minimum } \chi^{2}\end{array}$ & $\begin{array}{l}136 \cdot 4(22 \cdot 8) \\
146 \cdot 7(21 \cdot 4) \\
142 \cdot 2(21 \cdot 8)\end{array}$ & $\begin{array}{l}7334(5521-10918) \\
6818(5300-9556) \\
7030(5405-10053)\end{array}$ & $\begin{array}{l}0.864(3) \\
0.829(3) \\
0.789(3)\end{array}$ \\
\hline \multicolumn{4}{|l|}{ Anticolon antibody: } \\
\hline $\begin{array}{l}\text { Weighted mean } \\
\text { Maximum likelihood } \\
\text { Minimum } \chi^{2}\end{array}$ & $\begin{array}{l}1.21(0.45) \\
1.23(0.44) \\
1.34(0.46)\end{array}$ & 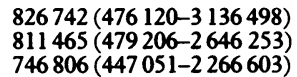 & $\begin{array}{l}1.545(3) \\
1.519(3) \\
1.460(3)\end{array}$ \\
\hline
\end{tabular}

found. Estimated frequencies of anticolon antibody secreting EBV transformed cells in mucosal lymphocytes were higher than those in peripheral blood lymphocytes. These data suggest that anticolon antibody secreting cells are richer in colonic mucosa than in peripheral blood, although the ability of EBV to transform the lymphocytes was not determined, and true frequencies of anticolon antibody secreting cells could not be obtained. It has been reported that IgG cells in the lamina propria of ulcerative colitis colon were appreciably increased in comparison with healthy control subjects. ${ }^{16}$ These IgG cells may contribute to produce anticolon antibody in the inflamed lesions. Limiting dilution culture study showed that approximately one per 140 IgG secreting lymphocytes in colonic mucosa was secreting anticolon antibody. These findings support an important role for colonic mucosa in the production of anticolon antibody. In addition, the local production of anticolon antibody may induce antibody dependent cell mediated cytotoxicity against colonic epithelial cells.

In this study we first established human monoclonal cell lines producing autoantibodies against colonic epithelial cells. It has never been reported that human anticolon antibody secreting cells have been found in patients with ulcerative colitis. Two IgG cell lines, which were cloned by limiting dilution culture, secreted anticolon antibodies constantly. The antigens which these two antibodies reacted with, however, were completely different in the immunohistochemial staining. One (DB5 $B_{11}$ ) reacted mainly with goblet cells. This kind of staining pattern has been described in previous studies using the sera from patients with ulcerative colitis. ${ }^{131417}$ The other $\left(\mathrm{CA} 6 \mathrm{H}_{3}\right)$ reacted with the apical portion of colon epithelial cells, but did not react with goblet cells. Although lymphocytes capable of secreting multiple-organ reactive autoantibodies are common in the repertoire of normal B lymphocytes, ${ }^{18}$ two monocolonal antibodies in this study did not react with any other organ tested. DB5 $\mathrm{B}_{11}$ antibody is similar to the monoclonal antibody which Vecchi et $a l^{19}$ developed using $40 \mathrm{kDa}$ proteins of colonic tissue, but CA6 $\mathrm{H}_{3}$ is different in the staining pattern from the other monoclonal antibody established by Das $e t a l^{20}$ which reacted mainly with basolateral areas of epithelial cells. The variety of reactivity of these monoclonal anticolon antibodies may be accounted for by the fact that various kinds of anticolon antibodies have been found in the sera of the patients with ulcerative colitis. It is still not clear which kind of antibody is most important in the pathogenesis of this disease.

The present study provides the evidence that the lymphocytes isolated from the inflamed mucosa or peripheral blood of patients with ulcerative colitis can secrete antibodies which react with colon epithelial cells. These antibodies may play an important part in cytolysis of colon epithelial cells through the antibody dependent cell mediated cytotoxicity mechanisms. Furthermore, the analysis of the components of colonic mucosa by these specific antibodies must be useful to define colon specific antigens and then 
to produce an experimental model of ulcerative colitis.

This work was supported by a grant from the Ministry of Health and Welfare in Japan.

1 Broberger O, Perlmann P. Autoantibodies in human ulcerative colitis. F Exp Med 1959; 110: 657-74.

2 Watson DW, Quigley A, Bolt RJ. Effect of lymphocytes from patients with ulcerative colitis on human adult colon epithelial cells. Gastroenterology 1966; 51: 985-93.

3 Marcussen $\mathrm{H}$. Fluorescent anti-colonic and $\mathrm{E}$ coli antibodies in ulcerative colitis. Scand $\mathcal{F}$ Gastroenterol 1978; 14: 277-81.

$4 \mathrm{Hibi} \mathrm{T}$, Aiso S, Ishikawa M, et al. Circulating antibodies to the surface antigens on colon epithelial cells in ulcerative colitis. Clin Exp Immunol 1983; 54: 163-8.

5 Broberger O, Perlmann P. In vitro studies of ulcerative colitis. I Reactions of patients' serum with human fetal colon cell I Reactions of patients' serum with human fetal colon
tissue culture colon cells. $\mathcal{F}$ Exp Med 1963; 117: 705-15.

6 Stobc JD, Tomasi TB, Huizenga KA, et al. In vitro studies of inflammatory bowel disease. Surface receptor of the mononuclear cell required to lyse allogeneic colonic epithelial cells. Gastroenterol 1976; 70: 171-6.

7 Hibi T, Aiso S, Yoshida T, et al. Anti-colon antibody and lymphocytophilic antibody in ulcerative colitis. Clin Exp Immunol 1982; 49: 75-80.

8 Das KM, Kadono Y, Fleischer GM. Antibody-dependent cellmediated cytotoxicity in serum samples from patients with ulcerative colitis. Am F Med 1984; 77: 791-6.

9 Auer IO, Grosch L, Hardorfer C, et al. Ulcerative colitis specific cytotoxic IgG-autoantibodies against colonic epithelial cells. Gut 1988; 29: 1639-47.
10 Bookman MA, Bull DM. Characteristics of isolated intestinal mucosal lymphoid cells in inflammatory bowel disease. Gastroenterology 1979; 77: 503-10.

11 Hammarstrom S, Langercrantz R, Perlmann P, et al. Immunological studies in ulcerative colitis. II. Colon antigens and human blood group $\mathrm{A}$ - and $\mathrm{H}$-like antigens in germfree rats. F Exp Med 1965; 122: 1075-86.

12 Langercrantz R, Hammarstrom S, Perlmann P, et al. Immunological studies in ulcerative colitis. Clin Exp Immunol 1966; 1: 263-76.

13 Wright R, Truelove SC. Autoimmune reactions in ulcerative colitis. Gut 1966; 7: 32-40.

14 Marcussen H, Nerup J. Fluorescent anti-colon and organspecific antibodies in ulcerative colitis. Scand $\mathcal{f}$ Gastroenterol 1973; 8: 9-15.

15 Yarchoan R, Tosato G, Blaese RM, et al. Limiting dilution analysis of Epstein-Barr virus-induced immunoglobulin production by human B cells. $\mathcal{F}$ Exp Med 1983; 157: bulin

16 Brandzaeg $P$, Baklien $\mathrm{K}$, Fausa $\mathrm{O}$, et al. Immunohistochemical characterization of local immunoglobulin formation in ulcerative colitis. Gastroenterology 1974; 66: 1123-36.

17 Chapaman RW, Cottone M, Selby WS, et al. Serum autoantibodies, ulcerative colitis and primary sclerosing cholangitis. Gut 1986; 27: 86-91.

18 Satoh J, Prabhakar BS, Haspel MV, et al. Human monoclonal autoantibodies that react with multiple endocrine organs. NEngl F Med 1983; 309: 217-22.

19 Vecchi M, Sakamaki S, Diamond B, et al. Development of a monoclonal antibody specifically reactive to gastrointestinal goblet cells. Proc Natl Acad Sci USA 1987; 84: 3425-9.

20 Das KM, Sakamaki S, Vecchi M, et al. The production and characterization of monoclonal antibodies to a human characterization of monoclonal antibodies to a human localization of the antigen by using monoclonal antibody. I Immunol 1987; 139: 77-84. 


\section{NOTES}

\section{Drugs and the liver: high risk patients and} transplantation

An international symposium will take place at the Hotel Executive, Milan, Italy, on 3-5 July 1991. Further information is available from the Organising Secretary, Fondazione Giovanni Lorenzini, Via Monte Napoleone 23, 20121 Milan, Italy (tel $39276002267-783868$, fax 392781511).

Mayo-European course in gastroenterology, 18-24 August 1991

This postgraduate course is co-sponsored by the Mayo Foundation and the Vienna Medical Education Office. It will be held in Vienna, Austria (18-21 August 1991); Budapest, Hungary (22, 23 August 1991); and Prague, Czechoslovakia (24 August 1991, optional). For further information contact Dr Siegfried Meryn, Congress Office, Mondial Congress, Faulmanngasse 4, A-1040 Vienna, Austria (tel
0222588040 , telex 0222111668 , fax 0222 5871268) or Dr S F Phillips, Gastroenterology Unit, Mayo Clinic, Rochester, MN 55905, USA.

European Association for the Study of the Liver (EASL)

The 26th meeting of EASL will take place on 11-14 September 1991 at Palma de Mallorca, Spain. Further information is available from the EASL Secretary, Professor J Reichen, Department of Pharmacology, Murtenstrasse 35, CH-3010-Berne (tel 4131 643570, fax 41 $31254713)$.

\section{European digestive disease week, 1991}

The European digestive disease week 1991 will be held in Amsterdam from 21-26 October, 1991 as a PanEuropean forum for clinicians and researchers in hepatology and gastroenterology.

Enquiries and registration forms are available from QLT/Congrex, Keizersgracht 782, 1017 EC Amsterdam, The Netherlands (tel 31 (0)20 261372, fax 31 (0)20 259574).

\section{Safer sclerotherapy - luer lock}

Doctors David Clements and Paul Smith of Llandough Hospital, South Glamorgan, suggest a simple change in practice that would improve the safety of endoscopy for staff. They commend the use of a luer lock syringe for the sclerosant when injecting varices. ${ }^{1}$ In the six months since adopting this practice they have avoided the hazard of being sprayed with slcerosant on occasions when the syringe detaches from the needle during injection.

Luer lock syringes are readily available and only marginally more expensive.

1 Herlithy KJ, Bozymski EM. Sclerotherapists eye Gastrointest Endosc 1982; 28: 42-3.

\section{Correction}

In vitro anticolon antibody production by mucosal or peripheral blood lymphocytes from patients with ulcerative colitis by T Hibi $e t a l$, December 1990; 31: 1371-6. In this paper in Figure 3 (colour plate) parts $a$ and $b$ were inverted and parts $c$ and $d$ were inverted; thus in the legend $a$ describes plate $b, b$ describes a $c$ describes $\mathrm{d}$ and $d$ describes $\mathrm{c}$. 